\title{
Priority Forests for Conservation in Fiji: landscapes, hotspots and ecological processes
}

\author{
David Olson, Linda Farley, Alex Patrick, Dick Watling, Marika Tuinawa \\ Vilikesa Masibalavu, Lemeki LenoA, Alivereti Bogiva, Ingrid QAuQAu \\ James Atherton, Akanisi Caginitoba, Moala Tokota'a, Sunil Prasad \\ Waisea Naisilisili, Alipate Raikabula, Kinikoto Mailautoka \\ Craig Morley and Thomas Allnutt
}

\begin{abstract}
Fiji's National Biodiversity Strategy and Action Plan encourages refinements to conservation priorities based on analyses of new information. Here we propose a network of Priority Forests for Conservation based on a synthesis of new studies and data that have become available since legislation of the Action Plan in 2001. For selection of Priority Forests we considered minimum-area requirements for some native species, representation goals for Fiji's habitats and species assemblages, key ecological processes and the practical realities of conservation areas in Fiji. Forty Priority Forests that cover $23 \%$ of Fiji's total land area and 58\% of Fiji's remaining native forest were identified. The analysis confirms the majority of conservation priority areas previously identified, recommends several new areas, and supports the Government of Fiji's policy
\end{abstract}

David Olson* (Corresponding author), Linda Farley, Alex Patrick, Ingrid Qauqau, James Atherton ${ }^{\dagger}$, Akanisi Caginitoba, Moala Tokota'a, Sunil Prasad ${ }^{\ddagger}$, Waisea Naisilisili, Alipate Raikabula and Кinikoto Mailautoka Wildlife Conservation Society-South Pacific Program, Suva, Fiji. E-mail conservationearth@live.com

Dick WatLing Environment Consultants Fiji, and NatureFiji-MareqetiViti, Suva, Fiji.

Marika Tuiwawa South Pacific Regional Herbarium, University of the South Pacific, Suva, Fiji.

Vilikesa Masibalavu BirdLife-Fiji, Suva, Fiji.

Lemeki LenoA (Deceased) Conservation International-Pacific Islands Program, Suva, Fiji

Alivereti Bogiva $^{\S}$ Fijian Affairs Board, Suva, Fiji.

CRAIG MORLEY ${ }^{\uparrow}$ Division of Environmental Sciences, University of the South Pacific, Suva, Fiji.

Thomas ALLNUTt UC Berkeley \& REBIOMA (WCS-Madagascar), Berkeley, California, USA.

${ }^{*}$ Current address: Conservation Earth Consulting, 4234 McFarlane Avenue, Burbank, California, 91505, USA.

${ }^{\dagger}$ Also at: Conservation International-Polynesia \& Micronesia Program, Apia, Samoa.

${ }^{\ddagger}$ Also at: Division of Environmental Sciences, University of the South Pacific, Suva, Fiji.

${ }^{\S}$ Current address: Institute of Applied Science, University of the South Pacific, Suva, Fiji.

${ }^{\top}$ Current address: Department of Conservation, Dargaville, New Zealand.

Received 18 January 2008. Revision requested 15 May 2008.

Accepted 24 July 2008. goal of protecting $40 \%$ of remaining natural forests to achieve the goals of the National Biodiversity Strategy and Action Plan and sustain ecosystem services for Fijian communities and economies.

Keywords Conservation priorities, ecosystem services, Fiji, forest conservation, national biodiversity strategy, Oceania, protected area network, representation

This paper contains supplementary material that can be found online at http://journals.cambridge.org

\section{Introduction}

The biodiversity of Fiji is increasingly being recognized 1 as a global conservation priority (Davis et al., 1996; Stattersfield et al., 1998; Myers et al., 2000; Government of Fiji, 2001; Ryan, 2001; Olson \& Dinerstein, 2002; Masibalavu \& Dutson, 2006). Fiji's unusual biogeographical history (Van Balgooy, 1971; Green \& Cullen, 1973; Kroenke, 1996; Hall, 2002; Evenhuis \& Bickel, 2006; Heads, 2006) has imparted an exceptionally diverse forest biota characterized by pronounced endemism at the level of species and higher taxa (Ash, 1982; Gibbons, 1984, 1985; Ash \& Vodonivalu, 1989; Davis et al., 1996; Heads, 2006) and the presence of numerous basal and primitive lineages (Ash, 1992; Miller, 1989; Hollingsworth, 2004), unusual radiations (Camponotus and Pheidole ants; Sarnat, 2006, 2008) and Gondwanan elements (Bickel, 2006; Davis et al., 1996).

The Government of Fiji, landowners, NGOs and the private sector have committed to protecting Fiji's natural forest heritage through the enactment of Fiji's National Biodiversity Strategy and Action Plan (Government of Fiji, 2001), the Fiji Departments of Forestry and Environment's forestry certification programmes (Fiji Department of Forestry, 2007), and the ongoing establishment and recognition of a number of national and community-based forest protected areas (e.g. community-declared protected areas of Waisali, Bouma, Koroyanitu, Kilaka and Naicuvalevu). The conservation priorities for Fiji's forests identified in the Action Plan were based on a synthesis of existing conservation analyses (Lees, 1989; Paine, 1989; Tabunakawai \& 
Chang, 1991; Watling \& Chape, 1992; Government of Fiji, 1993; Wright \& Lees, 1996) and consultations with biodiversity specialists (Government of Fiji, 1998a,b,c,d; Kretzschmar, 2000).

The Action Plan promotes the ongoing refinement of conservation priorities as new data and analyses become available (Government of Fiji, 2001). As a contribution to this process we have synthesized biodiversity information and conservation analyses (Fiji Important Bird Areas, Masibalavu \& Dutson, 2006; Critical Ecosystem Partnership Fund's Fiji Profile, Olson \& Farley, 2004; Key Biodiversity Areas, Conservation International, 2005) that have become available since 2001 and re-evaluated Priority Forests for Conservation. The Fiji Department of Forestry's (2007) policy goal of $40 \%$ of all extant natural forest (corresponding to $20 \%$ of Fiji's original natural forests) to remain forested provided a percentage target. Given this target, we asked which specific forests should be designated as Protection Forests (i.e. forests where the protection of native forest cover in a relatively undisturbed state is the primary management goal; Tabunakawai \& Chang, 1991; Watling, 1994) to achieve conservation and ecosystem service goals based on existing knowledge, principles of regional conservation strategies that have been evolving through similar efforts elsewhere (e.g. representation of distinct assemblages and habitats, maintaining ecological processes and ecosystem services, minimum-area requirements; Noss \& Cooperrider, 1994; Dinerstein et al., 2000; Groves, 2003; Jennings et al., 2003; Forest Stewardship Council PNG, 2006), and practical consideration of development trends and goals, and land use.

\section{Methods}

We employed a four-step approach to arrive at our recommended network of Priority Forests for Conservation:

(1) Information used in the preparation of the Biodiversity Strategy and Action Plan was reviewed. Data layers, such as existing protected areas, priority areas, natural forest cover and watersheds, were mapped. Using the geographical information systems MapInfo v. 8.5 (Pitney Bowes, Troy, USA) and ArcView v. 9.3 (ESRI, Redlands, USA) we overlaid watershed (Atherton et al., 2006) and topographic features with a map of remaining natural forests (Olson, 2006) based on Landsat Thematic Mapper imagery (1991-1995) and Fiji Department of Forestry (1996) vegetation maps.

(2) Studies published or otherwise available after the Action Plan was prepared were evaluated for relevant information (Keppel, 2002; Olson et al., 2002; Barker, 2003; Tuiwawa \& Naikatini, 2003a,b; Watling, 2003; WCS, 2003; Farley et al., 2004; Olson \& Farley, 2004; Yanega et al., 2004; Atherton, 2005; Conservation International, 2005; Keppel, 2005a,b,c; Keppel et al., 2005, 2006; Atherton et al., 2006; Chape, 2006; Evenhuis, 2006; Evenhuis \& Bickel,
2006; Heads, 2006; Masibalavu \& Dutson, 2006; Monaghan et al., 2006; Sarnat, 2006, 2008; Savu, 2006; Jackson \& Jit, 2007; Keppel \& Tuiwawa, 2007; Palmeirim et al., 2007; Rounds, 2007).

(3) Using a set of decision rules that considered natural habitats and ecological processes, representation of the full set of habitats and distinct species assemblages, and the realities of conservation (Table 1, Appendix 1), we assessed if there were any major gaps in how existing protected areas, priority areas and recently proposed priority areas (Olson \& Farley, 2004; Conservation International, 2005; Masibalavu \& Dutson, 2006) addressed these guidelines and decision rules. Generalized boundaries around Priority Forest blocks were then drawn using forest edges and watershed boundaries (Atherton et al., 2006) within contiguous forest if they corresponded to mataqali (i.e. traditional land ownership) and provincial boundaries. The emphasis on watershed boundaries is a practical consideration as landowners and logging companies can readily identify watershed boundaries when they are on the land. In some cases provincial and mataqali boundaries were used where they differed markedly from watershed boundaries.

(4) Priority areas not identified in previous analyses were highlighted and existing priorities confirmed, where appropriate.

We recognize that achieving agreement on the boundaries and management of protected areas often requires considerable negotiation with a variety of stakeholders, a process that will be influenced by many factors. Therefore, the generalized forest blocks delineated on our maps (Figs 1-3), and their biological justification, are more relevant to this process than the exact boundaries proposed.

The forest cover data we used date from 1991-1995 and there has been considerable logging activity since. We therefore assume that the current area, boundaries and distribution of forest cover are not exactly the same as those depicted on our maps but our collective field experience suggests that these changes are not of sufficient scale to alter our Priority Forest list. However, mapping of forest cover at a greater resolution, along with the distribution of major habitat types such as dry, transition and moist forest, is required. Current biogeographical knowledge is most comprehensive for birds and herpetofauna. Certain groups of plants, such as palms, are relatively well-studied, but the majority of taxa have not been the subject of extensive biogeographical study. Similarly, some genera and families of invertebrates and freshwater fish have recently been the subject of archipelagic-wide surveys (Sarnat 2006, 2008) but the majority of groups are understudied (Jenkins \& Boseto, 2003; Evenhuis \& Bickel, 2006). The second largest island of Vanua Levu, in particular, is poorly surveyed for a wide range of taxa. Koro, Gau, Yasayasamoala and the southern Lau Group are also inadequately surveyed. 
TABLE 1 Guiding principles and decision-rules for selection of Priority Forests for Conservation in Fiji. Appendix 1 provides the justification for the decision-rules.

\section{Habitat \& ecological processes}

A majority of the larger blocks of remaining natural forest $\left(>100 \mathrm{~km}^{2}\right)$

Forest refugia remote from alien predators (Olson et al., 2006)

Intact watersheds \& those forests that have a wide altitudinal range, particularly those with intact lowland forest (Atherton et al., 2006; Olson, 2005)

Forested watersheds adjacent to high conservation value reefs (WWF, 2005; Atherton et al., 2006)

\section{Representation}

All major islands \& island groups (Viti Levu, Vanua Levu \& Taveuni, Kadavu, Lomaiviti, Yasayasa Moala, Lau Group, Mamanuca Group, Yasawa Group, Rotuma)

All major habitat types within the four major islands: moist dry, transition \& montane forest. Small island forests are represented but not mangroves.

All major biotic provinces (Fig. 4), \& as many as possible of the biotic sub-provinces (Fig. 4) \& province/subprovinces for individual taxa (Appendix 2: Figs 5-8)

Known archipelagic-scale hotspots for endemism \& richness

Known sites of special conservation concern, such as the last large populations of Critically Endangered or endemic species

(Forest corridors that are critical for maintaining connectivity across larger forested landscapes were not identified)

\section{Conservation realities}

Larger blocks of forest where logging \& road-building are currently intense \& future logging is predicted were generally avoided (Atherton et al., 2006)

Watershed boundaries \& traditional ownership (mataqali) boundaries delineate larger forest blocks (Atherton et al., 2006) in most cases

The target for protection was c. $50 \%$ of the remaining natural forest

\section{Results}

\section{Habitats and ecological processes}

Forty areas (Table 2; Figs 1-3) were identified as Priority Forests for Conservation where protection should be the major management emphasis to achieve national-level conservation and ecosystem services goals. Together these areas cover $23 \%$ of the total land area and c. $58 \%$ of the remaining natural forest. Twenty-two large blocks $(>100$ $\mathrm{km}^{2}$ ) of remaining natural forest were identified for protection. Two of the largest blocks of natural forest, western Serua and Wainimala, both remote areas (Olson et al., 2006), were not selected as they are experiencing intensive logging and may lose much of their conservation value in the near future. These areas should be re-evaluated if this situation changes.

We highlight as a priority two forested corridors that presently connect increasingly isolated Priority Forest blocks.
These are: (1) the threatened Vunitorilau Corridor, which is the last undisturbed forest connection between the wider Sovi-Waimanu forests and the upland forests of Monasavu/ Tomanivi, as well as the Serua forest blocks; and (2) the corridor between Monasavu and Tomanivi, which is disappearing rapidly. Forests of the Nakauvadra Range and Mt Evans Ranges on Viti Levu are increasingly isolated from the main forest block. Forest corridors linking the larger forests blocks of the dividing range of Vanua Levu are also of critical importance.

The relatively intact watersheds of Taveuni, southern Vanua Levu, eastern Kadavu (Koronibanuve), and southwest Viti Levu (Waimanu) were all selected. These areas, along with Gau, Tunuloa/Natewa and Nakorotubu, support some of Fiji's last forests that range from lowland to montane habitats. Several smaller islands are largely covered in native forest, including Sawa-i-Lau, western Macuata Island, Yaduataba, Namenalailai, Makodroga, Vatuvara, Vuaqava, Ogea Levu and Ogea Driki. Several larger forested watersheds that are adjacent to Fiji's high conservation value reefs (WWF, 2005; Atherton et al., 2006) were also selected (Nakauvadra, Nakorotubu, Navotuvotu, Kubulau, Vatuvonu, Delaikoro, Dogutuki, and Ovalau) to help protect these marine ecosystems.

\section{Representation of distinct assemblages and habitats}

The 40 areas represent all of the major islands and island groups, and major forest habitat types within the major islands. Mangroves, wetlands, Pandanus savannahs and littoral forests were not analysed. Most of the remaining fragments of tropical dry forest are encompassed. Tropical dry forest was formerly widespread on the leeward side of the larger islands but now occurs only in small remnant patches (Mueller-Dombois \& Fosberg, 1998).

All proposed biotic provinces and sub-provinces (see Appendix 1 for a description of identification and delineation; Fig. 4), except for Wainimala and western Serua, are represented. The four larger islands with notable bird endemism (Viti Levu, Vanua Levu, Taveuni and Kadavu) are represented, as are the majority of Important Bird Areas (Masibalavu \& Dutson, 2006). All biotic provinces for reptiles and amphibians are represented but the important site of Yanuya Island, Ono-i-Lau (the only known locality for Leiolopisma alazon) is not captured (Morrison, 2003a,b, 2005; Appendix 2: Fig. 5; biotic subdivisions may be less relevant for the relatively widespread Fijian herpetofauna; Morrison, 2005). Provisional biogeographic subdivisions for freshwater fish (Jenkins \& Boseto, 2003; Appendix 2: Fig. 6) are all represented but two sites of special importance, the lower Sigatoka River and the Upper Lekutu River are not captured. All of the biotic provinces and sub-provinces for invertebrates (Appendix 2: Fig. 7) are represented except for the Wainimala Sub-province. 


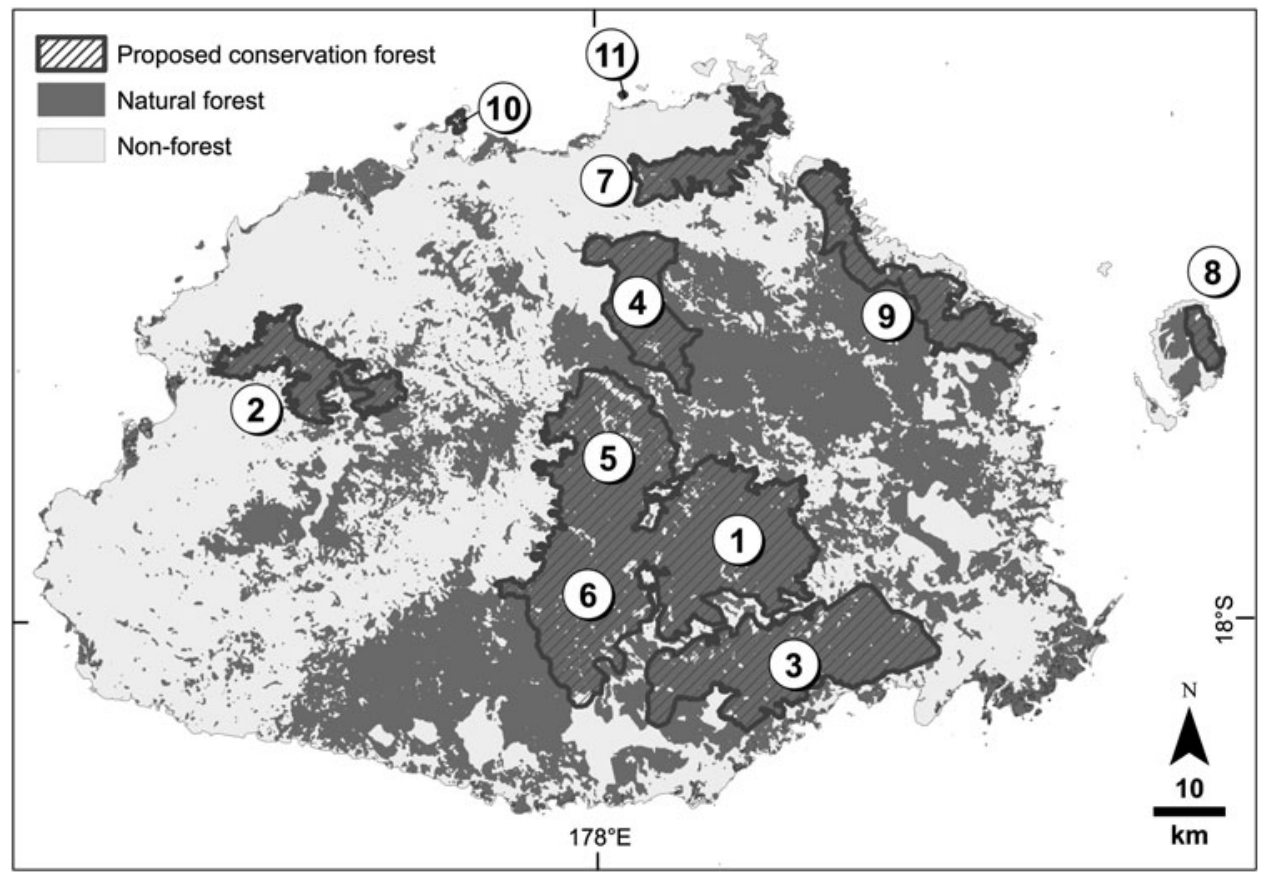

FIg. 1 Priority Forests for Conservation proposed for Viti Levu. 1, Sovi Basin \& Korobasabasaga; 2, Mt Evans/Koroyanitu/Abaca (Batilamu); 3, Waimanu (Nakobalevu to Nakoro); 4, Tomanivi/Wabu; 5, Nadrau Plateau; 6, Eastern Serua; 7, Nakauvadra; 8, Ovalau; 9, Nakorotubu; 10, Vatia; 11, Macuata Island.

Proposed biotic provinces for plants are all represented but the Wainimala Sub-province is not captured and two sites of special importance, central Kadavu and several sites with restricted-range palm species along the southern coast of Viti Levu and the southern Rewa River valley, are not captured (Fuller, 1997; Doyle \& Fuller, 1998; Zona \& Fuller, 1999; Watling, 2005; Appendix 2: Fig. 8).
Several areas known to have high alpha richness of plants (south-eastern Viti Levu: Tuiwawa \& Doyle, 1998; Tuiwawa \& Naikatini, 2003b; Vatuvonu and Kubulau, Vanua Levu: Government of Fiji, 1994; Kretzschmar, 2000) and invertebrates (Mt Evans/Koroyanitu/Abaca, Kubulau, Tomanivi/Wabu and Waimanu; Sarnat, 2006; S. Prasad et al., unpubl. data) are priorities. Areas notable

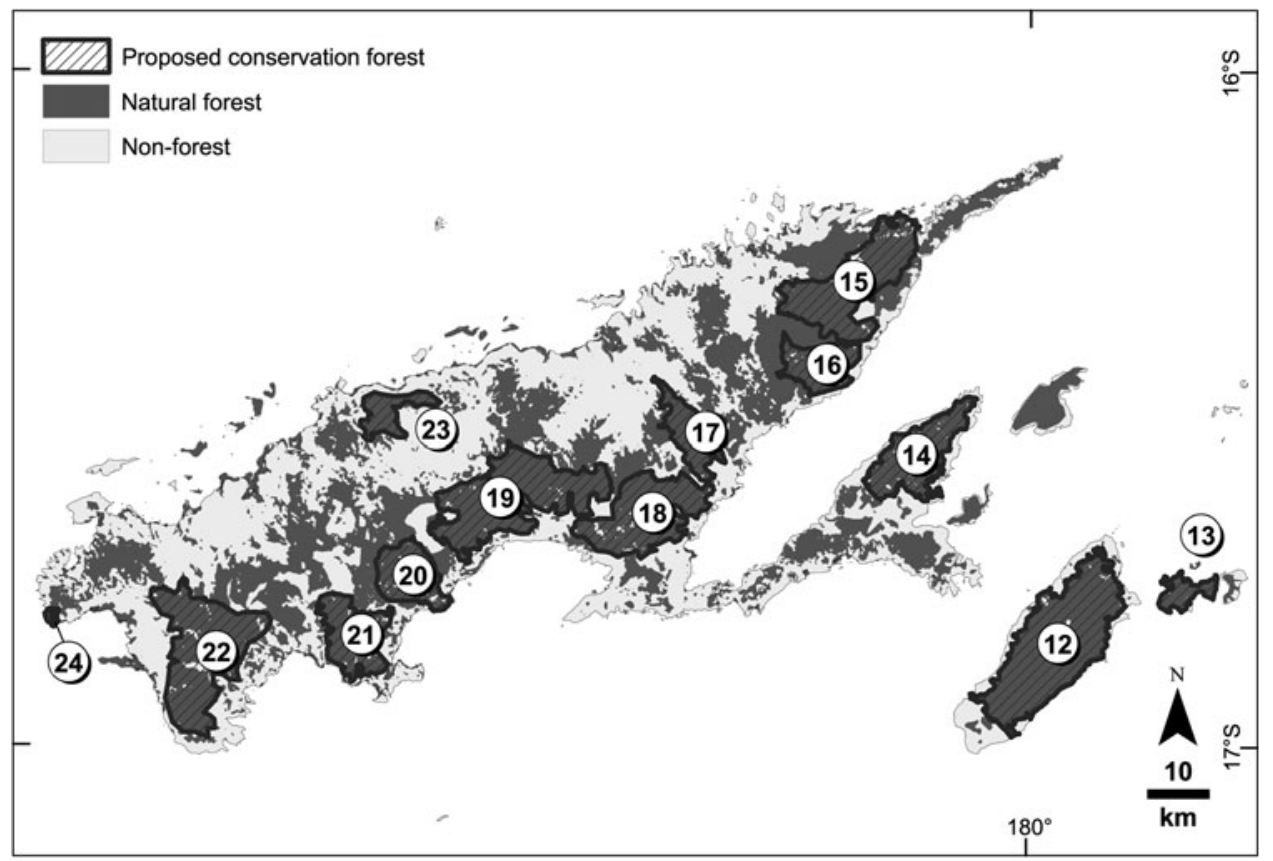

FIG. 2 Priority Forests for Conservation proposed for Vanua Levu and Taveuni. 12, Taveuni Forest Reserve \& Bouma National Heritage Park; 13, Qamea \& Laucala; 14, Tunuloa/Natewa; 15, Dogutuki; 16, Saqani; 17, Dikeva; 18, Koroalau; 19, Delaikoro; 20, Vatuvonu (Tavea-Valili); 21, Kubulau; 22, Navotuvotu; 23, Rokosalase; 24, Naicobocobo. 


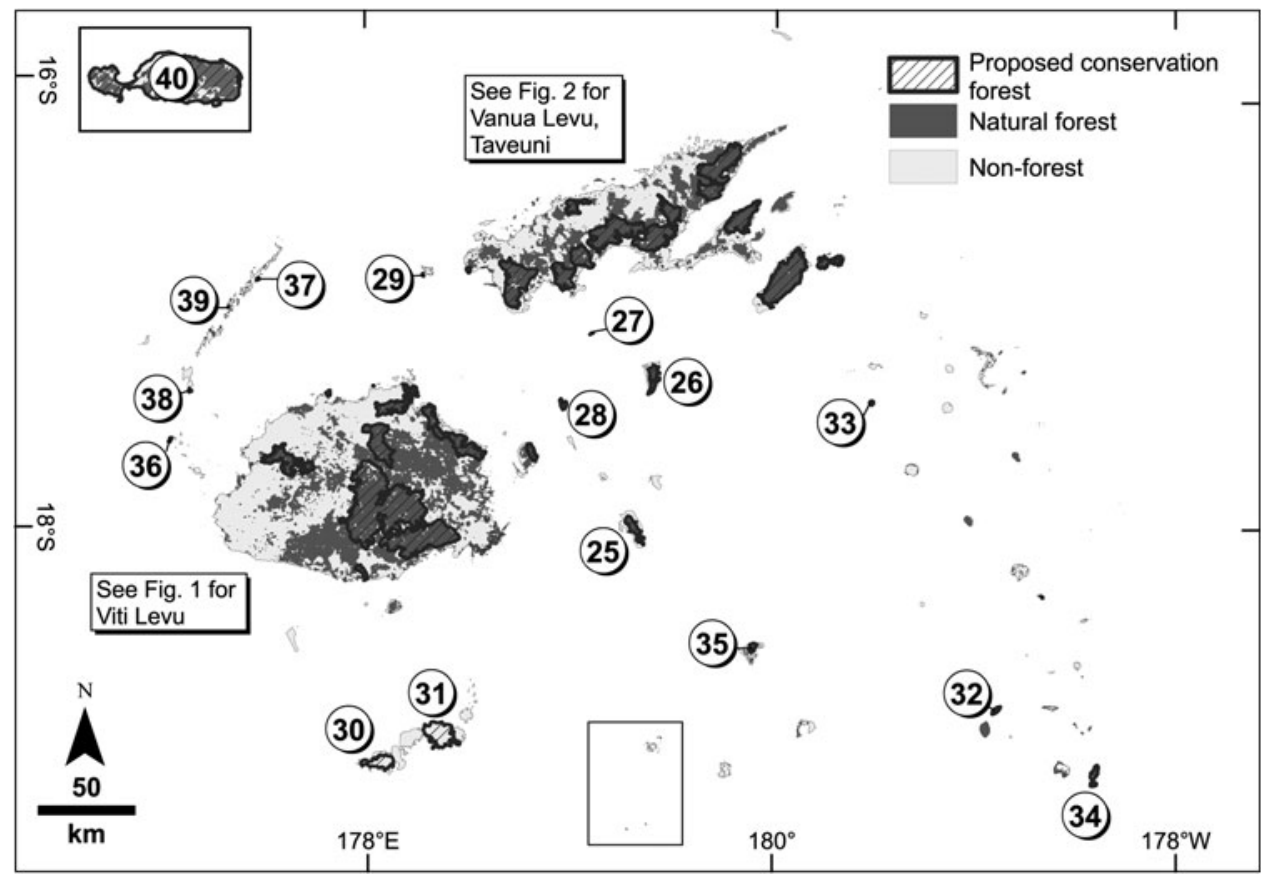

FIG. 3 Priority Forests for Conservation proposed for Outer Islands of Fiji. 25, Gau; 26, Kuitarua, Koro; 27, Namenalailai; 28, Makodroga; 29, Yaduataba; 30, Delaivuiivi (Nabukelevu or Mt Washington); 31, Koronibanuve; 32, Vuaqava; 33, Vatu Vara; 34, Ogea Levu \& Ogea Driki; 35, Moala; 36, Monuriki \& Mono; 37, Sawa-i-Lau; 38, Kuata; 39, Devuilau; 40, Rotuma.

for concentrations of endemic plants and invertebrates are also represented, including Kadavu, the cloud and montane forests of central Viti Levu, Mt Evans Range (Thaman, 1996; Thaman et al., 1999), and south-eastern Viti Levu; hotspots within this area include Waimanu, Mt Voma, Korobasabasaga, Mt Naitaradamu, and eastern Serua (Watkins, 1994; Tuiwawa, 1999). Other endemism hotspots include Taveuni, Gau and Koro. The latter two may have the most distinctive invertebrate fauna, in terms of percentage single-island endemism, of all the Fijian islands (Barker, 2003; E. Sarnat, pers. comm.; S. Prasad et al., unpubl. data).

The largest known populations of the Critically Endangered Fijian crested iguana Brachylophus vitiensis are selected, representing the Viti Levu (Macuata Island), Mamanuca (Monuriki and Mono), Yasawa (Devuilau), and the presumptive Vanua Levu (Yaduataba) forms (Gibbons, 1981; Laurie et al., 1987; Harlow \& Biciloa, 1999, 2000; Olson et al., 2002; Olson \& Keppel, 2004; Harlow et al., 2007). The broad distribution of the Priority Forests may also capture some of the poorly known geographical variation of the banded iguana Brachylophus fasciatus.

The unusual karst habitats of Sawa-i-Lau are represented but known karst habitats of Wailotua and several of the Lau Group islands are not (Heads, 2006). The Priority Forests within the Lau and Yasayasamoala Groups are probably underrepresented in this analysis. Two of the largest extant sago palm Metroxylon vitiense swamps, Maratu and Wainikevu (Rounds, 2007), are included in the Serua and Waimanu forest blocks, respectively. Sago swamps on Vanua Levu are not represented, and the few documented swamps near Savusavu are small and threatened. Fiji's tropical dry forests are represented on Macuata Island, Yadua Taba, Rokosalase and Naicobocobo. Mangroves and seabird and sea-snake islands (Government of Fiji, 2001; Masibalavu \& Dutson, 2006) were not analysed.

\section{Comparisons to previous priority-setting analyses}

This analysis confirms existing priorities identified in the Fiji National Biodiversity Strategy and Action Plan (i.e. the Department of Environment's List of Sites of National Significance and Nature Reserves) and highlights several new areas of conservation importance, namely the Nakauvadra Range, the Waimanu region (south-east Viti Levu), eastern Serua, Macuata Island, Koro, Sawa-i-Lau, Nakorotubu, Yasayasamoala Group, Vatuvara, Kuata, Devuilau, Aiwa Levu and Aiwa Lailai, Vuaqava, and much of the remaining forest of southern Vanua Levu including Navotuvotu, Kubulau, Vatuvonu, Korolau (the larger forested landscape around Waisali Reserve), Dikeva and Sagani. Several of these new areas were previously identified in the Critical Ecosystem Partnership Fund's Fiji assessment (Olson \& Farley, 2003; Conservation International, 2005), Important Bird Areas (IBAs would cover $39 \%$ of the remaining natural forest if implemented; Masibalavu \& Dutson, 2006) and Conservation International's (2005) Key Biodiversity Areas (KBA) draft analysis. The western and central portions of Serua (Serua Forest Wilderness and Upper Navua Gorge KBAs) and the Nausori Highlands 
TABLE 2 The 40 identified priority forests for conservation (Figs 1-3), with description and justification, whether a Fiji Biodiversity Strategy and Action Plan Site of Biological Significance (FBSAP; Government of Fiji, 2001), Important Bird Area (IBA; Masibalavu \& Dutson, 2006) or Key Biodiversity Area (KBA; Conservation International, 2005), and any site-specific references. The Critical Ecosystem Partnership Fund Profile Priority Areas for Fiji (Olson \& Farley, 2005) informed the development of the Key Biodiversity Areas. Alternate names given by different priority-setting efforts are provided where needed.

\begin{tabular}{|c|c|c|c|c|c|c|}
\hline $\begin{array}{l}\text { Island/island } \\
\text { group }\end{array}$ & $\begin{array}{l}\text { Priority Forest for } \\
\text { Conservation (PFC) }\end{array}$ & Description \& justification & FBSAP & IBA & KBA & References \\
\hline Viti Levu & $\begin{array}{l}\text { 1, Sovi Basin \& } \\
\text { Korobasabasaga }\end{array}$ & $\begin{array}{l}\text { The largest block of extant lowland forest, surrounded by } \\
\text { steep ranges, remote forest, endemism foci along ridges, } \\
\text { landowner negotiations for conservation advanced, } \\
\text { conservation funding prospects good }\end{array}$ & Yes & Sovi Basin & Yes & $\begin{array}{l}\text { Tuiwawa \& Doyle (1998), } \\
\text { Tuiwawa (1999), Tuiwawa } \\
\text { \& Naikatini (2003a), Watling } \\
(2003,2006)\end{array}$ \\
\hline Viti Levu & $\begin{array}{l}\text { 2, Mt Evans/ } \\
\text { Koroyanitu/ } \\
\text { Abaca (Batilamu) }\end{array}$ & $\begin{array}{l}\text { High local endemism in plants \& invertebrates (possibly the } \\
\text { most pronounced invertebrate endemism locality; D. Bickel, } \\
\text { pers. comm.), scenic landscape \& steep terrain, good existing } \\
\text { protection \& landowner interest }\end{array}$ & Yes & $\begin{array}{l}\text { Koroyanitu/ } \\
\text { Vaturu }\end{array}$ & Yes & $\begin{array}{l}\text { Thaman (1996), Thaman } \\
\text { et al. (1999) }\end{array}$ \\
\hline Viti Levu & $\begin{array}{l}\text { 3, Waimanu } \\
\text { (Nakobalevu } \\
\text { to Nakoro) }\end{array}$ & $\begin{array}{l}\text { High local endemism \& richness, highest richness for leaf } \\
\text { litter invertebrate samples (S. Prasad et al., unpubl. data), } \\
\text { relatively intact watersheds, scenic ranges, close to capital, } \\
\text { Waimanu Forest Reserve established by landowners }\end{array}$ & Yes & $\begin{array}{l}\text { Viti Levu } \\
\text { southern } \\
\text { highlands }\end{array}$ & Korobaba & $\begin{array}{l}\text { Bush (1997), Watling (2003), } \\
\text { Keppel et al. (2005) }\end{array}$ \\
\hline Viti Levu & 4, Tomanivi/Wabu & $\begin{array}{l}\text { Highest forests, high local endemism \& concentrations of } \\
\text { endemic taxa, Nadarivatu has highest alpha native ant } \\
\text { diversity (E. Sarnat, pers. comm.), critical watershed for } \\
\text { Sigatoka \& Wainimala Rivers }\end{array}$ & Yes & $\begin{array}{l}\text { Greater } \\
\text { Tomanivi }\end{array}$ & Yes & Keppel (2005b) \\
\hline Viti Levu & 5, Nadrau Plateau & Plateau of highland forest, many endemics & Yes & Rairaimatuku highlands & Yes & \\
\hline Viti Levu & 6, Eastern Serua & $\begin{array}{l}\text { Largest block of remaining forest, likely foci for endemism, } \\
\text { logging \& degradation increasing, landownership issues } \\
\text { complex, critical watershed for Navua River }\end{array}$ & No & $\begin{array}{l}\text { Possible } \\
\text { additional IBA }\end{array}$ & $\begin{array}{l}\text { E portion of } \\
\text { Serua Forest } \\
\text { Wilderness }\end{array}$ & Bush (1997) \\
\hline Viti Levu & 7, Nakauvadra & $\begin{array}{l}\text { Large block of wet-dry transitional forest, intact altitudinal } \\
\text { transect on southern slope, important watershed for Vatu-i-Ra } \\
\text { coral reefs }\end{array}$ & No & No & Yes & \\
\hline Viti Levu & 8 , Ovalau & $\begin{array}{l}\text { Highland block of forest represents the only Viti Levu forests } \\
\text { without mongoose Herpestes spp. impact }\end{array}$ & Yes & $\begin{array}{l}\text { Possible } \\
\text { additional IBA }\end{array}$ & Yes & \\
\hline Viti Levu & 9, Nakorotubu & $\begin{array}{l}\text { Unusual transition forests, poorly known biologically, some } \\
\text { karst habitats, important watersheds adjacent to high } \\
\text { conservation value coral reefs of the Vatu-i-Ra }\end{array}$ & No & No & Yes & \\
\hline Viti Levu & 10, Vatia & $\begin{array}{l}\text { Largest remaining block of Viti Levu dry forest with good } \\
\text { restoration potential \& community interest }\end{array}$ & No & No & Yes & $\begin{array}{l}\text { Keppel \& Tuiwawa } \\
(2007)\end{array}$ \\
\hline Viti Levu & 11, Macuata Island & $\begin{array}{l}\text { Driest form of highly threatened Fijian dry forest, without } \\
\text { alien predators (except rats Rattus spp.) or grazers, last } \\
\text { known population of Viti Levu form of Critically } \\
\text { Endangered Fijian crested iguana Brachylophus vitiensis }\end{array}$ & No & No & No & $\begin{array}{l}\text { Olson \& Keppel (2004), } \\
\text { Keppel (2005a) }\end{array}$ \\
\hline Taveuni & $\begin{array}{l}\text { 12, Taveuni Forest } \\
\text { Reserve \& Bouma } \\
\text { National Heritage } \\
\text { Park }\end{array}$ & $\begin{array}{l}\text { One of two remaining large forested landscapes in the } \\
\text { Oceanic Pacific that extends from the mountains to the sea, } \\
\text { one of three largest islands with no mongoose in oceanic } \\
\text { Pacific, high single-island \& archipelagic endemism, scenic } \\
\text { coastline, Taveuni Highlands IBA, FBSAP Site of Biological } \\
\text { Significance, KBA }\end{array}$ & Yes & $\begin{array}{l}\text { Taveuni } \\
\text { highlands }\end{array}$ & Yes & Ash (1988) \\
\hline
\end{tabular}




\begin{tabular}{|c|c|c|c|c|c|c|}
\hline Taveuni & 13, Qamea \& Laucala & $\begin{array}{l}\text { Well-forested islands next to Taveuni with distinct } \\
\text { populations of several bird species }\end{array}$ & No & No & $\begin{array}{l}\text { Laucala } \\
\text { is a KBA }\end{array}$ & \\
\hline Vanua Levu & 14, Tunuloa/Natewa & $\begin{array}{l}\text { Relatively distinct biota from the rest of Vanua Levu, } \\
\text { unusual affinities with Taveuni \& Waimanu forests of Viti } \\
\text { Levu based on plants \& invertebrates, distinct races of } \\
\text { endemic birds }\end{array}$ & Yes & $\begin{array}{l}\text { Natewa/ } \\
\text { Tunuloa }\end{array}$ & Natewa & \\
\hline Vanua Levu & 15, Dogutuki & $\begin{array}{l}\text { Largest relatively intact watershed in Vanua Levu adjacent to } \\
\text { high conservation value Cakau Levu Reef, distinct forest } \\
\text { types }\end{array}$ & Yes & No & Vunivia & $\begin{array}{l}\text { Lees (1989), Bogiva (1993), } \\
\text { Keppel et al. (2006) }\end{array}$ \\
\hline Vanua Levu & 16, Saqani & Rugged mountains with interesting plant endemism & No & No & No & \\
\hline Vanua Levu & 17, Dikeva & $\begin{array}{l}\text { Rugged mountains, representative moist forest with } \\
\text { local plant endemism }\end{array}$ & No & No & No & \\
\hline Vanua Levu & 18, Koroalau & $\begin{array}{l}\text { Large block of forest acting as a corridor between Dikeva \& } \\
\text { Delaikoro, important watershed for Savusavu Bay \& Natewa } \\
\text { Bay, local plant endemism }\end{array}$ & No & No & No & \\
\hline Vanua Levu & 19, Delaikoro & $\begin{array}{l}\text { Large block of forest in mountainous terrain, very high } \\
\text { richness of plant \& invertebrates, good populations of Vanua } \\
\text { Levu birds including long-legged thicketbird Trichocichla } \\
\text { rufa, important watershed for Savusavu Bay, Waisali Reserve } \\
\text { of National Trust for Fiji }\end{array}$ & No & $\begin{array}{l}\text { Wailevu-Dreketi } \\
\text { Highlands }\end{array}$ & $\begin{array}{l}\text { Waisali } \\
\text { KBA site }\end{array}$ & \\
\hline Vanua Levu & $\begin{array}{l}\text { 20, Vatuvonu } \\
\text { (Tavea-Valili) }\end{array}$ & $\begin{array}{l}\text { Highest known single-site tree richness (alpha diversity) for } \\
\text { Vanua Levu, rugged peaks, important watersheds for coastal } \\
\text { reefs \& Namena Reef, one of Fiji's highest priority reef } \\
\text { complexes }\end{array}$ & No & No & $\begin{array}{l}\text { Mt Kasi is a } \\
\text { KBA site } \\
\text { within this site }\end{array}$ & $\begin{array}{l}\text { Government of Fiji } \\
\text { (1994), Kretzschmar } \\
\text { (2000) }\end{array}$ \\
\hline Vanua Levu & 21, Kubulau & $\begin{array}{l}\text { Highest invertebrate richness for Vanua Levu based on } \\
\text { malaise trap surveys of Fiji Arthropod Survey, rich plant } \\
\text { communities, important watershed for high conservation } \\
\text { value reefs of Namena \& Wainunu }\end{array}$ & No & No & No & Keppel (2005c) \\
\hline Vanua Levu & 22, Navotuvotu & $\begin{array}{l}\text { High montane forest in Bua, poorly known, important } \\
\text { watersheds for high conservation value reefs of western } \\
\text { Vanua Levu \& Vatu-i-Ra Channel }\end{array}$ & No & No & $\begin{array}{l}\text { Mt Navotuvotu } \\
\text { is a KBA site }\end{array}$ & \\
\hline Vanua Levu & 23, Rokosalase & $\begin{array}{l}\text { Good example of Vanua Levu dry/transition forest, last } \\
\text { relatively intact buabua (Fragraea spp.), high conservation } \\
\text { interest of landowners }\end{array}$ & Yes & No & No & \\
\hline Vanua Levu & 24, Naicobocobo & $\begin{array}{l}\text { Largest \& most intact block of Vanua Levu form of Fijian dry } \\
\text { forest }\end{array}$ & No & No & Naicobocobo & $\begin{array}{l}\text { Keppel \& } \\
\text { Tuiwawa (2007) }\end{array}$ \\
\hline Lomaiviti Group & $25, \mathrm{Gau}$ & $\begin{array}{l}\text { Large, single block of moist forest with a wide altitudinal } \\
\text { range, high \% single-island endemism, island-endemic Fiji } \\
\text { petrel Pterodroma macgillivrayi breeds here }\end{array}$ & Yes & $\begin{array}{l}\text { Gau } \\
\text { highlands }\end{array}$ & Gau & \\
\hline Lomaiviti Group & 26, Kuitarua, Koro & $\begin{array}{l}\text { Faunal similarity analyses of leaf litter invertebrate taxa } \\
\text { suggest Koro \& Gau's fauna is among the most distinctive in } \\
\text { Fiji (S. Prasad et al., unpubl. data), important for protection } \\
\text { of local reefs \& fisheries }\end{array}$ & No & No & No & \\
\hline
\end{tabular}


TABLE 2 (Continued)

\begin{tabular}{|c|c|c|c|c|c|c|}
\hline Lomaiviti Group & 27, Namenalailai & Intact small island forest & Yes & No & No & \\
\hline Lomaiviti Group & 28, Makodroga & Intact small island forest & Yes & No & No & \\
\hline Lomaiviti Group & 29, Yaduataba & $\begin{array}{l}\text { Protected, good example of Fijian dry forest \& home of } \\
\text { largest remaining population of Fijian crested iguana, good } \\
\text { degree of existing protection, restoration potential \& } \\
\text { landowner interest, National Trust for Fiji Yaduataba } \\
\text { Reserve }\end{array}$ & Yes & No & Yes & $\begin{array}{l}\text { Laurie et al. (1987), } \\
\text { Olson et al. (2002) }\end{array}$ \\
\hline Kadavu & $\begin{array}{l}\text { 30, Delaivuiivi } \\
\text { (Nabukelevu or } \\
\text { Mt Washington) }\end{array}$ & $\begin{array}{l}\text { Montane forest with known endemics, under threat } \\
\text { (Nabukelevu is a more recognizable geographical name for } \\
\text { this area) }\end{array}$ & Nabukulevu & Yes & $\begin{array}{l}\text { Nabukelevu/Mt } \\
\text { Washington }\end{array}$ & \\
\hline Kadavu & 31, Koronibanuve & $\begin{array}{l}\text { Largest block of intact forest \& watersheds on Kadavu with } \\
\text { good populations of island endemics, important watersheds } \\
\text { for reefs }\end{array}$ & Yes & East Kadavu & No & \\
\hline Lau Group & 32, Vuaqava & A relatively intact southern Lau Group forest with low threat & No & No & Yes & \\
\hline Lau Group & 33, Vatu Vara & $\begin{array}{l}\text { Intact high island with good populations of Endangered } \\
\text { banded iquanas Brachylophus fasciatus, one of the highest } \\
\text { raised limestone islands in the world }(300 \mathrm{~m})\end{array}$ & No & No & No & \\
\hline Lau Group & $\begin{array}{l}\text { 34, Ogea Levu \& } \\
\text { Ogea Driki }\end{array}$ & $\begin{array}{l}\text { Ogea monarch flycatcher Mayrornis versicolor restricted to } \\
\text { these islands, relatively intact representative forests }\end{array}$ & Yes & Ogea & $\begin{array}{l}\text { Only Ogea } \\
\text { Levu is a } \\
\text { KBA }\end{array}$ & Watling (1988) \\
\hline $\begin{array}{l}\text { Yasayasamoala } \\
\text { Group }\end{array}$ & 35, Moala & $\begin{array}{l}\text { Representative forest block in central Moala, Yasayasamoala } \\
\text { Group has locally endemic invertebrates (E. Sarnat, pers. } \\
\text { comm.) }\end{array}$ & No & No & No & \\
\hline $\begin{array}{l}\text { Mamanuca-i-Cake } \\
\text { Group }\end{array}$ & $\begin{array}{l}\text { 36, Monuriki \& } \\
\text { Mono }\end{array}$ & $\begin{array}{l}\text { Last dry forest remnants of Mamanuca Group with } \\
\text { dwindling populations of Mamanuca form of Fijian crested } \\
\text { iguana }\end{array}$ & Yes & No & $\begin{array}{l}\text { Monuriki is } \\
\text { a KBA }\end{array}$ & $\begin{array}{l}\text { Harlow \& Biciloa } \\
(1999,2000), \text { Keppel } \\
\text { (2004), Harlow et al. (2007) }\end{array}$ \\
\hline Yasawa Group & 37, Sawa-i-Lau & $\begin{array}{l}\text { One of the best examples of threatened Fijian dry forest, best } \\
\text { example of Yasawan dry forest, karst landscape, uplifted } \\
\text { limestone island, high landowner interest in protection, } \\
\text { possible translocation site for Yasawa Group race of Fijian } \\
\text { crested iguanas, rugged terrain inhibits deforestation }\end{array}$ & No & No & No & \\
\hline Yasawa Group & 38 , Kuata & Good example of threatened small island dry forest & No & No & No & Harlow et al. (2007) \\
\hline Yasawa Group & 39, Devuilau & $\begin{array}{l}\text { Last good example of Yasawan dry forest with remnant } \\
\text { population of Fijian crested iguana }\end{array}$ & No & No & No & Harlow et al. (2007) \\
\hline Rotuma & 40, Rotuma & $\begin{array}{l}\text { Isolated island } 465 \mathrm{~km} \text { north of Fiji, several island-endemic } \\
\text { species \& populations of regionally threatened species }\end{array}$ & Yes & Rotuma & No & $\begin{array}{l}\text { Robinson (1975), } \\
\text { Zug et al. (1988), } \\
\text { McClatchey et al. (2000), } \\
\text { Rigamoto (2000), } \\
\text { Masibalavu \& } \\
\text { Dutson (2006) }\end{array}$ \\
\hline
\end{tabular}

largest remaining population of Fijian crested iguana, good

(Nabukelevu or

Mt Washington) ulations of Endangered hese islands, relatively intact representative forest

Group has locally endemic invertebrates (E. Sarnat, pers.

comm.) iguana rested iguanas, rugged terrain inhibits deforestation

population of Fijian crested iguan

solated island $465 \mathrm{~km}$ north of Fiji, several island-endemic Yes pecies \& populations of regionally threatened species 


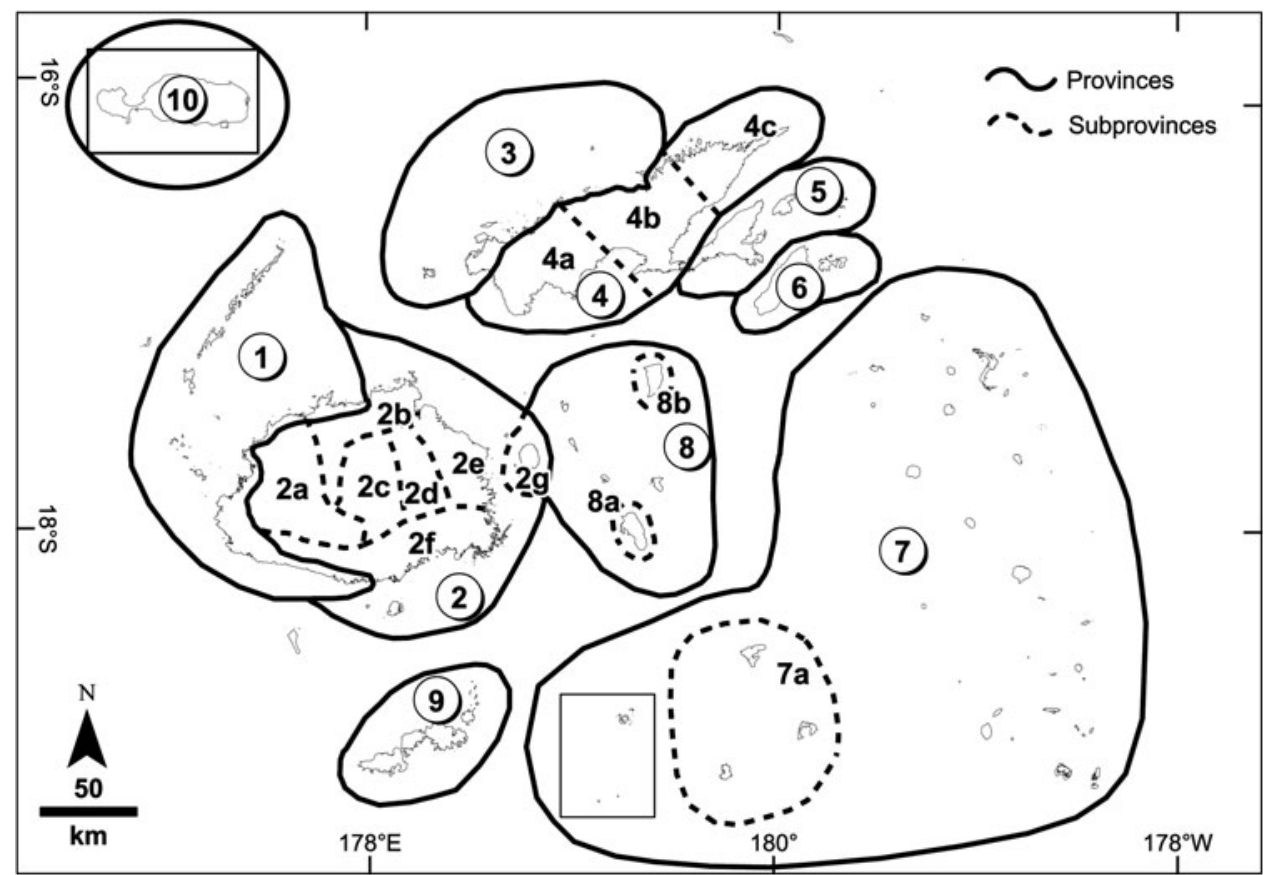

FIG. 4 Preliminary biotic provinces and sub-provinces for Fiji (see Appendix 2). 1, Viti Levu Dry Forest; 2, Viti Levu Moist Forest; 2a, Mt Evans-Nausori; 2b, Nakauvadra-Tuvuca; 2c, Tomaniivi-Nadrau; 2d, Wainimala; 2e, Korotuba-Sawakasa; 2f, South-east Viti Levu; 2g, Ovalau; 3, Vanua Levu Dry Forest; 4, Vanua Levu Moist Forest; 4a, Western Vanua Levu; 4b, Central Vanua Levu; 4c, Eastern Vanua Levu; 5, Natewa; 6, Taveuni; 7, Lau Group; 7a, Yasayasa Moala Group; 8, Lomaiviti Group; 8a, Gau; 8b, Koro; 9, Kadavu; 10, Rotuma.

KBA were not selected as Priority Forests because of the intensive logging in these areas.

\section{Discussion}

This Priority Forests for Conservation analysis confirms and complements previously identified priorities for the archipelago, including those of Fiji's National Biodiversity Strategy and Action Plan (Government of Fiji, 2001). There is strong consensus amongst Fiji's conservation community on important areas for protection, and the list and areas of proposed priorities continues to expand as knowledge of the archipelago's biodiversity increases and conservation strategies are refined. The Priority Forest map also addresses a broad range of conservation and ecosystem service goals. If all the Priority Forests and proposed marine priority areas (WWF, 2005) could be designated for protection, Fiji would have one of the most comprehensive and robust systems of protected areas (IUCN/ UNEP, 1986; Rodrigues et al., 2004).

National development goals and the needs and aspirations of local people (Government of Fiji, 2004, 2005) may, however, preclude protection for the entire proposed Priority Forest network. However, our analysis suggests that the Government of Fiji's (Fiji Department of Forestry, 2007) policy goal of protecting $40 \%$ of Fiji's remaining forests may represent a minimum threshold, below which unacceptable losses of biodiversity may occur, both in forests and coastal marine ecosystems. Levels of $10-20 \%$ for protected areas that are commonly discussed in conservation negotiations (Desmet \& Cowling, 2004; Svancara et al., 2005) are inadequate to protect the full range of species in the archipelago. Recent biogeographical studies (Watling, 2005; Heads, 2006; Sarnat, 2008) suggest that patterns of local endemism in Fiji may be more complex than previously documented, especially for invertebrates and plants. Multiple and widespread protected forests will be needed to represent the biota adequately.

Protecting $<40 \%$ of Fiji's remaining natural forest may also compromise important ecosystem services. Almost every remaining native forest has communities living within it, downstream, or utilizing coastal resources influenced by run-off. At a minimum, upper watersheds should all be protected, as indicated in Fiji's Forest Function map (Watling, 1994), for their role in maintaining healthy freshwater and coastal fisheries, diminishing flood impacts, providing clean water, enhancing local rainfall and seasonal water availability, and as a source of non-timber forest products. Fiji's islands are sufficiently small that the effects of altering watersheds are immediately and dramatically felt in freshwater and coastal marine ecosystems, with cascading effects on subsistence and commercial fisheries and community health.

The current proliferation of high-impact logging operations in smaller coastal watersheds of Vanua Levu and Viti Levu is probably one of the major drivers of degradation in 
Fiji's freshwater and coastal resources (Atherton et al., 2006). Greater weight should be given to the critical role of intact forests in providing ecosystem services to Fiji's people and economy, and the substantial economic value of these services needs to be recognized and integrated into cost/benefit analyses and planning (Cambie \& Ash, 1994; Government of Fiji, 1998b; Balmford et al., 2002). Fiji's efforts to develop a certification programme for forestry operations reflects a growing recognition of the importance of ecosystem services provided by protected forests (Fiji Department of Forestry, 2007).

If a protected area system based on the Priority Forest network is put in place then the entire forest product industry in Fiji could potentially receive a national-level forestry certification (i.e. landscape-scale certification; Farley et al., 2004), as long as standards relating to logging practices, social values, and High Conservation Value Forests (i.e. a certification category of the Forestry Stewardship Council's widely-adopted certification programme that emphasizes a narrower range of conservation considerations; Forest Stewardship Council, 2003; Jennings et al., 2003) are upheld. While challenging to implement (Gullison, 2003; Lenoa, 2003; Sesega, 2003), the economic and societal benefits of landscape-scale forestry certification may, in the long-term, outweigh those from certifying single operations (Pierce \& Ervin, 2003; Farley et al., 2004; Olson, 2006).

The Government of Fiji continues to work towards the commitment it made in 2007 to protect $40 \%$ of its remaining natural forest. Our analysis recommends $58 \%$ protection to achieve conservation and ecosystem service goals. We, collectively, are thinking at a similar scale of protection, a pre-condition for success in the task that lies ahead, working with landowners and the forest industry to turn protection goals into reality.

\section{Acknowledgements}

We thank the Government of Fiji for their interest and support, the landowners for their interest, support and permission to work in their forests and for their hospitality and generosity. We are indebted to Fiji's Department of Environment (DOE), particularly to Manasa Sovaki and Epeli Nasome; the Department of Forestry (MAFF), particularly to Susana Tuisese, Inoke Wainiqolo, Joe Ceinturaga and Sanjana Lal; and Fiji Fisheries, particularly Aisake Batibasaga and Sunia Waiqanabete. We are grateful for the support and assistance of the Fijian Affairs Board, Provincial governments and traditional leaders and councils. We appreciate and recognize the following organizations for sharing data and expertise for our analyses: MAFF, DOE, Native Land Trust Board, The Pacific Islands Applied Geoscience Commission, Fiji Department of Lands and Survey, Fiji Hydrology, Mineral Resource Department, The National Trust for Fiji, University of the South Pacific,
BirdLife, South Pacific Regional Herbarium, WWF and Wetlands International. This study was supported by a grant from the East Asia and Pacific Environment Initiative Program of the US Agency for International Development (Fiji Forestry Landscape Certification Project). Additional support came from the US Department of State, the US National Science Foundation Fiji Arthropod Survey Project, and the Schlinger Foundation. One of the authors, Lemeki Lenoa, passed away before completion of this study. We dedicate this paper to him, a great colleague and among Fiji's most committed and enlightened foresters and conservationists. We thank John Morrison, Neal Evenhuis, Dan Bickel, Eli Sarnat and two anonymous reviewers for reviewing earlier drafts.

\section{References}

Ash, J. (1988) Stunted cloud-forest in Taveuni, Fiji. Pacific Science, $41,191-199$.

Ash, J. (1992) Vegetation ecology of Fiji: past, present, and future perspectives. Pacific Science, 46, 111-127.

AsH, J. \& Ash, W. (1984) Freshwater wetland vegetation of Viti Levu, Fiji. New Zealand Journal of Botany, 22, 377-391.

Ash, J. \& Vodonivalu, S. (1989) Fiji. In Floristic Inventory of Tropical Countries: The Status of Plant Systematics, Collections, and Vegetation, Plus Recommendations for the Future (eds D.G. Campbell \& D.H. Hammond), pp. 166-176. New York Botanic Gardens, New York, USA.

Atherton, J. (ed.) (2005) Ecosystem Profile: Polynesia-Micronesia Biodiversity Hotspot. Final draft submitted to the Critical Ecosystem Partnership Fund. Conservation International \& Secretariat of the Pacific Regional Environment Programme, Apia, Samoa.

Atherton, J., Olson, D., Farley, L. \& Qauqau, I. (2006) Watershed Assessment for Healthy Reefs and Fisheries: Fiji Watersheds at Risk. Technical Report submitted to the Fiji Department of Environment and Fiji Department of Fisheries by the Wildlife Conservation Society-South Pacific, Suva, Fiji.

Balmford, A., Bruner, A., Cooper, P., Costanza, R., Farber, S., GreEN, R.E. et al. (2002) Economic reasons for conserving wild nature. Science, 297, 950-953.

Barker, G. (2003) Biotic Regionalization of Fiji and Priorities for Reserve Networks: Land Snails. Technical Report prepared for the Wildlife Conservation Society-South Pacific, Suva, Fiji.

Bickel, D.J. (2006) Parentia (Diptera: Dolichopodidae) from Fiji: a biogeographic link with New Caledonia and New Zealand. Bishop Museum Occasional Papers, 89, 45-50.

Bogiva, A. (1993) Vunivia Catchment Reserve Proposal, Dogotuki, Macuata: A Field Investigation Report. Fiji Department of Forestry, Environmental Forestry Division, Colo-I-Suva, Fiji.

Brownlie, G. (1977) The Pteridophyte Flora of Fiji. J. Cramer, Vaduz, Liechtenstein.

Bush, E. (1997) The ecology and conservation biology of Acmopyle sahniana Buchh. \& N.E. Gray (Podocarpaceae). MSc thesis, University of the South Pacific, Suva, Fiji.

Cambie, R.C. \& Ash, J. (1994) Fijian Medicinal Plants. CSIRO, Collingwood, Australia.

Chape, S. (2006) Assessment of the Suitability of Placing the Taveuni Forest Reserve and Ravilevu Nature Reserve on Fiji's World Heritage Tentative List. Report prepared for BirdLife International Fiji, Fiji National Committee for World Heritage \& The National Trust for Fiji, Suva, Fiji. 
Conservation International (2005) Conservation Outcomes: Polynesia and Micronesia, Fiji Inset, Draft Map, 1:3,200,00o. Conservation International \& The Critical Ecosystem Partnership Fund, Washington, DC, USA.

Davis, S.D., Heywood, V.H. \& Hamilton, A.C. (eds) (1996) Centres of Plant Diversity: A Guide and Strategy for their ConservationAsia, Australasia and the Pacific Ocean. WWF \& IUCN, Cambridge, UK.

Desmet, P. \& Cowling, R. (2004) Using the species-area relationship to set baseline targets for conservation. Ecology and Society, 9, 11. Http://www.ecologyandsociety.org/vol9/iss2/artı1/ [accessed 24 April 2009].

Dinerstein, E., Powell, G., Olson, D., Wikramanayake, E., Abell, R., Loucks, C. et al. (2000) A Workbook for Conducting Biological Assessments and Developing Biodiversity Visions for Ecoregion-based Conservation. WWF, Washington, DC, USA.

Doyle, M.F. \& Fuller, D. (1998) Palms of Fiji-1, endemic, indigenous and naturalised species: changes in nomenclature, annotated checklist, and discussion. Harvard Papers in Botany, $3,95-100$.

Duffels, J.P. (1988) The Cicadas of Fiji, Samoa, and Tonga Islands: Their Taxonomy and Biogeography. Entomonograph 10. E.J. Brill/ Scandinavian Science Press, Vinderup, Denmark.

Evenhuis, N.L. (2006) The genus Holorusia Loew (Diptera: Tipulidae) from Fiji. Bishop Museum Occasional Papers, 85, 3-21.

Evenhuis, N.L. \& Bickel, D.J. (2006) The NSF-Fiji Terrestrial Arthopod Survey: overview. Bishop Museum Occasional Papers, $82,3-25$.

Farley, L., Olson, D. \& Patrick, A. (2004) Conservation of Fiji's Forests \& Wildlife: Building Conservation Landscapes into Forestry Operations \& Forest Certification. Technical Report submitted to the Fiji Department of Environment \& Fiji Department of Forestry, Wildlife Conservation Society-South Pacific, Suva, Fiji.

Fij Department of Forestry (1996) Vegetation Map of the Fiji Islands. Government of Fiji, Suva, Fiji.

Fiji Department of Forestry (2007) Forest Policy Statement. Government of Fiji, Suva, Fiji.

Forest Stewardship Council (2003) FSC Principles and Criteria. FSC, Bonn, Germany.

Forest Stewardship Council-Papua New Guinea (2006) High Conservation Value Forest Toolkit. PNG-FSC, Port Moresby, Papua New Guinea. Http://www.panda.org/what_we_do/how_we_work/ conservation/forests/tools/hcvf_toolkit/ [accessed 1 September 2009].

FULLER, D. (1997) Conservation status, diversity and systematics of the indigenous palms of Fiji. MSc thesis, University of the South Pacific, Suva, Fiji.

Giввоns, J.R.H. (1981) The biogeography of Brachylophus (Iguanidae) including the description of a new species, B. vitiensis, from Fiji. Journal of Herpetology, 15, 255-273.

Gibbons, J.R.H. (1984) Iguanas of the South Pacific. Oryx, 18, 82-91.

Gibions, J.R.H. (1985) The biogeography and evolution of Pacific island reptiles and amphibians. In Biology of Australasian Frogs and Reptiles (eds G. Grigg, R. Shine \& H. Ehmann), pp. 125-143. Surrey Beatty and Sons, Sydney, Australia.

Government of FiJ (1993) The National Environment Strategy (eds D. Watling \& S. Chape). IUCN, Suva, Fiji.

Government of Fij (1994) Fiji-German Forestry Project/GTZ: Fiji's Natural Forest Inventory, Terms, Method and Results (1991-1993). Technical Report prepared by GOPA Consultants, FGFP/GTZ Technical Report, Suva, Fiji.

Government of FijI (1998a) FBSAP TG2: Terrestrial Vertebrates and Invertebrates. Technical Group 2 Report. Fiji Biodiversity Strategy and Action Plan, Department of Environment, Suva, Fiji.
GovernMENT OF FII (1998b) FBSAP TG3: Botanical Biodiversity Report. Technical Group 3 Report. Fiji Biodiversity Strategy and Action Plan, Department of Environment, Suva, Fiji.

Government OF FIJI (1998c) FBSAP TG5: The Economic Value of Fiji's Ecosystems. Technical Group 5 Report. Fiji Biodiversity Strategy and Action Plan, Department of Environment, Suva, Fiji.

GovernMENT OF FIJI (1998d) FBSAP TG7: Location and Justification of Priority Sites for the Conservation of Fiji's Biodiversity in the Marine Environment. Technical Group 7 Report. Fiji Biodiversity Strategy and Action Plan, Department of Environment, Suva, Fiji.

Government of FijI (2001) Fiji Biodiversity Strategy and Action Plan (FBSAP). Department of Environment, Suva, Fiji.

Government of FijI (2004) Millennium Development Goals: Fiji National Report. National Planning Office, Ministry of Finance and National Planning, Suva, Fiji.

Government of FIJI (2005) Strategic Development Plan: Rebuilding Confidence for Stability and Growth for a Peaceful, Prosperous Fiji. Draft. National Planning Office, Ministry of Finance and National Planning, Suva, Fiji.

Green, D. \& Cullen, D.J. (1973) The tectonic evolution of the Fiji region. In The Western Pacific (ed. P.J Coleman), pp. 127-145. University of Western Australia Press, Perth, Australia.

Groves, C.R. (2003) Drafting a Conservation Blueprint. The Nature Conservancy, Washington, DC, USA.

Gullison, R.E. (2003) Does forest certification conserve biodiversity? Oryx, 37, 153-165.

HALL, R. (2002) Cenozoic geological and plate tectonic evolution of SE Asia and the SW Pacific: computer-based reconstructions and animations. Journal of Asian Earth Sciences, 20, 353-434.

Harlow, P.S. \& Biciloa, P.N. (1999) The Population Status of the Crested Iguana (Brachylophus vitensis) on Monuriki Island, Mamanuca Group, Fiji. Technical Report prepared for The National Trust for Fiji \& The Department of Environment, Suva, Fiji.

Harlow, P.S. \& Biciloa, P.N. (2000) Abundance of the Fijian crested iguana (Brachylophus vitiensis) on two islands. Biological Conservation, 98, 223-231.

Harlow, P.S., Fisher, M., Tuifawa, M. Biciloa, P.N., Palmeirim, J., Mersai, C. et al. (2007) The decline of the endemic Fijian crested iguana in the Yasawa and Mamanuca archipelagos, western Fiji. Oryx, 41, 44-50.

Haynes, A. (1998a) The Land Snails of Fiji. Report of Technical Group 2. Fiji Biodiversity Strategy and Action Plan, Department of Environment, Government of Fiji, Suva, Fiji.

Haynes, A. (1998b) The Freshwater Invertebrates of Fiji. Report of Technical Group 2. Fiji Biodiversity Strategy and Action Plan, Department of Environment, Government of Fiji, Suva, Fiji.

Heads, M. (2006) Seed plants of Fiji: an ecological analysis. Biological Journal of the Linnean Society, 89, 407-431.

Hollingsworth, B. (2004) The evolution of iguanas: an overview of relationships and a checklist of species. In Iguanas: Biology and Conservation (eds A.C. Alberts, R.L. Carter, W.K. Hayes \& E.P. Martins), pp. 19-44. University of California Press, Berkeley, USA.

IUCN/UNEP (1986) Review of the Protected Areas System in Oceania. Cambridge University Press, Cambridge, UK.

JACKson, D. \& Jit, R. (2007) Population density and detectability of three Fijian forest birds. Notornis, 54, 99.

Jenkins, A.P. \& Boseto, D. (2003) A Preliminary Investigation of Priority Ichthyofaunal Areas for Assessing Representation in Fiji's Network of Forest Reserves. Technical Report of Wetlands International-Oceania \& Wildlife Conservation Society-South Pacific, Suva, Fiji. 
Jennings, S., Nussbaum, R., Judd, N. \& Evans, T. (2003) High Conservation Value Forest Toolkit. Edition 1. WWF \& IKEA Cooperation on Forests Project, ProForest, Oxford, UK. Http://assets.panda.org/downloads/hcvf_toolkit_part_1_final.pdf [accessed 24 April 2009].

Keppel, G. (2002) Coastal vegetation of Taunova Bay, Pacific Harbour, Viti Levu, Fiji-a proposed development site. South Pacific Journal of Natural Sciences, 20, 25-29.

Keppel, G. (2004) Vascular Plants, Vegetation and Conservation Perspectives on Monuriki Island, Southern Mamanucas, Republic of the Fiji Islands: Preliminary Observation. Technical Report submitted to the Wildlife Conservation Society-South Pacific \& The National Trust for Fiji, Suva, Fiji.

Keppel, G. (2005a) Vascular Plants and Vegetation of Macuata Island, Vunitogoloa, Ra, Viti Levu, Republic of the Fiji Islands. Technical Report submitted to the Wildlife Conservation SocietySouth Pacific \& The National Trust for Fiji, Suva, Fiji.

Keppel, G. (2005b) Botanical studies within the PABITRA Wet-Zone Transect, Viti Levu, Fiji. Pacific Science, 59, 165-174.

Keppel, G. (2005c) Summary Report on Forests of the Mataqali Nadicake Kilaka, Kubulau District, Bua, Vanua Levu: A Proposed Forest Watershed Reserve. Technical Report submitted to the Wildlife Conservation Society-South Pacific, Suva, Fiji.

Keppel, G., Cawani Navuso, J., Naikatini, A., Thomas, N.T., Rounds, I.A., Osborne, T.A. et al. (2005) Botanical diversity at Savura, a lowland rain forest site along the PABITRA Gateway Transect, Viti Levu, Fiji. Pacific Science, 59, 175-191.

Keppel, G., Rounds, I.A. \& Thomas, N.T. (2006) The flora, vegetation, and conservation value of mesic forest at Dogotuki, Vanua Levu, Fiji Islands. New Zealand Journal of Botany, 44, 273-292.

Keppel, G. \& Tuiwawa, M. (2007) Dry zone forests of Fiji: species composition, life history traits, and conservation. New Zealand Journal of Botany, 45, 545-563.

Kretzschmar, J.S. (2000) The Location of Biodiversity Hotspots in Fiji: An Analysis of Tree Biodiversity. Technical Group 7 Report. Fiji Biodiversity Strategy and Action Plan, Department of Environment, Government of Fiji, Suva, Fiji.

Kroenke, L.W. (1996) Plate tectonic development of the western and south-western Pacific: Mesozoic to the present. In The Origin and Evolution of Pacific Island Biotas, New Guinea to Eastern Polynesia: Patterns and Processes (eds A. Keast \& S.E. Miller), pp. 19-34. SPB Academic Publishing, Amsterdam, The Netherlands.

Laurie, W.A., Uryu, H. \& Watling, D. (1987) A faunal survey of Yaduataba Island reserve with particular reference to the crested iguana (Brachylophus vitiensis Gibbons 1981). Domodomo, $5,16-28$.

Lees, A. (1989) Representative National Parks and Reserves System for Fiji's Tropical Forests. Maruia Society Policy Reports Series No. 9. Maruia Society \& Bird Protection Society, Nelson, New Zealand.

Lenoa, L. (2003) Assessing the Efficacy of Landscape Forest Certification for Strengthening Fiji's Forest Reserve Network. Technical Report prepared for the Wildlife Conservation Society-South Pacific, Suva, Fiji.

Masibalavu, V.K. \& Dutson, G. (2006) Important Bird Areas in Fiji: Conserving Fiji's Natural Heritage. BirdLife International Pacific Partnership Secretariat, Suva, Fiji.

McClatchey, W., Thaman, R. \& Vodonaivalu, S. (2000) A preliminary checklist of the flora of Rotuma with Rotuman names. Pacific Science, 54, 345-363.

Miller, J.M. (1989) The archaic flowering plant family Degeneriaceae: its bearing on an old enigma. National Geographic Research, 5, 218-231.
Monaghan, M.T., Balke, M., Pons, J. \& Vogler, AP. (2006) Beyond barcodes: complex DNA taxonomy of a South Pacific island radiation. Proceedings of the Royal Society B, 273, 887-893.

Morley, C.G. (2004) Has the invasive mongoose Herpestes javanicus yet reached the island of Taveuni, Fiji? Oryx, 38, 457-460.

Morrison, C. (2003a) Forest Conservation in Fiji: Herpetological Provinces for Assessing Representation in Fiji's Forest Reserve Network. Technical Report prepared for the Wildlife Conservation Society-South Pacific, Suva, Fiji.

Morrison, C. (2003b) A Field Guide to the Herpetofauna of Fiji. Institute of Applied Science, University of the South Pacific, Suva, Fiji.

Morrison, C. (2005) Distribution and diversity of Fiji's terrestrial herpetofauna: implications for forest conservation. Pacific Science, $59,481-489$.

Mueller-Dombois, D. \& Fosberg, F.R. (1998) Vegetation of the Tropical Pacific Islands. Springer-Verlag, New York, USA.

Myers, N., Mittermeier, R.A., Mittermeier, C.G., Da Fonseca, G.A.B. \& Kent, J. (2000) Biodiversity hotspots for conservation priorities. Nature, 403, 853-858.

Noss, R.F. \& Cooperrider, A. (1994) Saving Nature's Legacy: Protecting and Restoring Biodiversity. Defenders of Wildlife \& Island Press, Washington, DC, USA.

Olson, D.M. (2006) Fiji's National Forest Policy Statement: Wildlife Conservation Society Comments on Draft Statement. Invited Report to Fiji Department of Forestry (MAFF) by the Wildlife Conservation Society-South Pacific, Suva, Fiji.

Olson, D.M. \& Dinerstein, E. (2002) The Global 200: priority ecoregions for global conservation. Annals of the Missouri Botanical Garden, 89, 199-224.

Olson, D.M. \& Farley, L. (eds) (2004) Polynesia-Micronesia Hotspot Ecosystem Profile \& Five-year Investment Strategy-Fiji Subregional Profile. Technical Report for the Critical Ecosystem Partnership Fund, Suva, Fiji.

Olson, D.M., Farley, L., Naisilisili, W., Raikabula, A., Prasad, O., Atherton, J. \& Morley, C. (2006) Remote forest refugia for Fijian wildlife. Conservation Biology, 20, 568-572.

Olson, D.M., Farley, L. \& Patrick, A. (2004) Conservation of Fiji's Forests \& Wildlife: Building Conservation Landscapes into Forestry Operations \& Forest Certification. Report presented to Fiji's Ministry of Fisheries and Forests. Wildlife Conservation Society-South Pacific, Suva, Fiji.

Olson, D.M. \& KeppeL, G. (2004) Results of a Rapid Survey for the Presence of Fiji's Crested Iguana (Brachylophus fasciatus) on Macuata Island, Vunitogoloa, Ra Province, Viti Levu, Republic of the Fiji Islands. Technical Report submitted to Fiji Department of Environment by the Wildlife Conservation Society-South Pacific, The National Trust for Fiji, University of the South Pacific Biology Department \& South Pacific Regional Herbarium, Suva, Fiji.

Olson, D.M., Tuiwawa, M.V., Niukula, J., Bicoloa, P., Keppel, G., Naikatini, A. et al. (2002) Conservation of Fijian Dry Forest and Fijian Crested Iguanas on Yadua Taba Island. Technical Report to The National Trust for Fiji by the Wildlife Conservation Society, South Pacific Regional Herbarium \& University of the South Pacific, Suva, Fiji.

Paine, J.R. (1989) Fiji: An Overview of its Protected Areas System. World Conservation Monitoring Centre, Cambridge, UK.

Palmeirim, J.M., Champion, A., Naikatini, A., Niukula, J., Tuiwawa, M., Fisher, M. et al. (2007) Distribution, status and conservation of bats of the Fiji Islands. Oryx, 41, 509-519.

Parkinson, B., Hemmen, J. \& Groh, K. (1987) Tropical Landshells of the World. Kyodo-Shing Loong Printing Industries Pte. Ltd, Singapore, Singapore. 
Pernetta, J.C. \& Watling, D. (1979) The introduced and native terrestrial vertebrates of Fiji. Pacific Science, 32, 223-243.

Pierce, A.R. \& Ervin, J.B. (2003) Can Independent Forest Management Certification Incorporate Elements of Landscape Ecology? Forest Stewardship Council, Minneapolis, USA.

Rigamoto, R.R. (2000) A floristic survey of the coastal littoral vegetation of Rotuma. MSc thesis, University of the South Pacific, Suva, Fiji.

Robinson, G.S. (1975) The Macrolepidoptera of Fiji and Rotuma. E.W. Classey, London, UK.

Rodrigues, A.S.L., AкÇakaya, H.R., Andelman, S.J., Bakarr, M.I., Boitani, L., Brooks, T.M. et al. (2004) Global gap analysis: priority regions for expanding the global protected-area network. BioScience, 54, 1092-1100.

Rounds, I. (2007) Conservation, management, and ethnobotany of sago (Metroxylon vitiense) in South-East Viti Levu, Fiji Islands. MSc thesis, University of the South Pacific, Suva, Fiji.

Ryan, P.A. (2001) Fiji's Natural Heritage. Exisle Publishing Ltd, Auckland, New Zealand.

SARnA T, E.M. (2006) Lordomyrma (Hymenoptera: Formicidae) of the Fiji Islands. Bishop Museum Occasional Papers, 90, 9-42.

SARnA T, E.M. (2008) A taxonomic revision of the Pheidole roosevelti group (Hymenoptera: Formicidae) in Fiji. Zootaxa, 1767, 1-36.

SAvU, S. (2006) Background Report for the Review of Natural Sites on Fiji's Tentative World Heritage List. Draft Report for The National Trust for Fiji, Suva, Fiji.

Sesega, S. (2003) Forest Conservation in Fiji: Assessing the Efficacy of Forest Certification for Strengthening Fiji's Forest Reserve Network. Technical Report prepared for the Wildlife Conservation Society-South Pacific, Suva, Fiji.

Smith, A.C. (1951) The vegetation and flora of Fiji. The Scientific Monthly, 7, 3-15.

Sмiтн, A.C. (1979-1996) Flora Vitiensis Nova: A New Flora of Fiji. Pacific Tropical Botanical Garden, Kalāheo, Hawaii.

Stattersfield, A.J., Crosby, M.J., Long, A.J. \& Wege, D.C. (1998) Endemic Bird Areas of the World: Priorities for Biodiversity Conservation. Burlington Press, Cambridge, UK.

Svancara, L.K., Brannon, R., Scott, J.M., Groves, C.R. \& Pressey, R.L. (2005) Policy-driven versus evidence-based conservation: a review of political targets and biological needs. BioScience, 55, 989-994.

Siminerton, K. \& Maljkovic, A. (2002) Preliminary Report on the Status and Distribution of the Red-throated Lorikeet Charmosyna amabilis in Fiji. Technical Report submitted to The National Trust for Fiji \& World Parrot Trust, Suva, Fiji.

Tabunakawai, K.M. \& Chang, A. (1991) Register of Nature, Forest Reserve and Protected Forests in Fiji. Fiji Department of Forestry, Suva, Fiji.

Thaman, R.R. (1996) The biodiversity of Koroyanitu National Park. Domodomo, 10, 20-51.

Thaman, R.R., Whistler, W.A., Vodonaivalu, S. \& Tuiwawa, M. (1999) The Flora of the Koroyanitu Massif and Conservation Area, Ba Province, Western Viti Levu, Fiji Islands. Technical Report 99-02, Institute of Applied Science \& South Pacific Regional Herbarium, University of the South Pacific, Suva, Fiji.

Tillyard, R.J. (1924) The dragonflies (Order Odonata) of Fiji, with special reference to a collection made by Dr. H.W. Simmonds, F.E.S., on the island of Viti Levu. Transactions of the Entomological Society London, 3-4, 305-345.

TuiwawA, M. (1999) The flora, ecology, and conservation of the botanical biodiversity of Waisoi and the south-eastern slopes of the Korobasabasaga Range in Namosi Province, Fiji. MSc thesis, University of the South Pacific, Suva, Fiji
Tuiwawa, M. \& Doyle, M. (1998) Preliminary checklist of the flora of Waisoi-Namosi and the surrounding area. The South Pacific Journal of Natural Science, 16, 28-36.

Tuinawa, M. \& Naikatini, A. (2003a) Baseline Flora and Fauna Survey of the Sovi Basin, Naitasiri. South Pacific Regional Herbarium, Wildlife Conservation Society-South Pacific, BirdLife International, Wetlands International \& University of the South Pacific, Suva, Fiji.

Tuiwawa, M. \& Naikatini, A. (2003b) Report of the Preliminary Baseline Survey of the Flora and Vegetation of Waivaka South, Namosi Province, Fiji. Mineral Resources Department (Fiji), Japan International Co-operation Agency, MMAJ Mineral Exploration Project, Viti Levu South, Suva, Fiji.

Van BAlgooy, M.M.J. (1971) Plant geography of the Pacific. Blumea Supplement, 8, 1-222.

W At Kins, A. (1994) A biogeographic database for seed plants of Fiji: a preliminary communication. South Pacific Journal of Natural Science, 15, 75-96.

Watling, D. (1988) Notes on the ecology and status of the Ogea Flycatcher Mayrornis versicolor. Bulletin of the British Ornithological Club, 108, 103-112.

W A t Ling, D. (1994) Determination of Potential Forest Functions. Fiji Department of Forestry, Suva, Fiji.

Watling, D. (1998) Conservation Status of Fijian Mammals and Freshwater and Land Birds (Draft). Report of Technical Group 2. Fiji Biodiversity Strategy and Action Plan, Department of Environment, Government of Fiji, Suva, Fiji.

Watling, D. (2001) A Guide to the Birds of Fiji and Western Polynesia including American Samoa, Niue, Samoa, Tokelau, Tonga, Tuvalu and Wallis \& Futuna. Environment Consultants Fiji, Suva, Fiji.

Watling, D. (2003) Report of the Preliminary Baseline Survey of the Terrestrial Vertebrate Fauna of the Waivaka Catchment, Namosi, Viti Levu. IAS Technical Report No. 2003/02. South Pacific Regional Herbarium, University of the South Pacific, Suva, Fiji.

Watling, D. (2005) Palms of the Fiji Islands. Environmental Consultants Fiji, Suva, Fiji.

Watling, D. (2006) Sovi Basin-Report on Review for Management Plan Preparation. Report prepared for The National Trust for Fiji, Suva, Fiji.

Watulng, D. \& Chape, S.A. (eds) (1992) Environment Fiji: The National State of the Environment Report. IUCN, Gland, Switzerland.

Watling, D. \& Zug, G.R. (1998) Annotated List and Conservation Status of Fijian Terrestrial Reptiles and Amphibians. Report of Technical Group 2. Fiji Biodiversity Strategy and Action Plan, Department of Environment, Government of Fiji, Suva, Fiji.

WCS (Wildlife Conservation Society) (2003) Heritage Trees of Fiji. Technical Report to the Department of Environment \& Fijian Affairs Board by the Wildlife Conservation Society-South Pacific, Suva, Fiji.

Whittier, H.O. (1975) A preliminary list of Fijian mosses. Florida Scientist, 38, 85-106.

Woodroffe, C.D. (1987) Pacific island mangroves: distribution and environmental settings. Pacific Science, 41, 166-185.

Wright, S.D. \& Lees, A.M. (1996) Biodiversity conservation in the island Pacific. In The Origin and Evolution of Pacific Island Biotas, New Guinea to Eastern Polynesia: Patterns and Processes (eds A. Keast \& S.E. Miller), pp. 445-461. SPB Academic Publishing, Amsterdam, The Netherlands.

WWF (2005) Setting Priorities for Marine Conservation: The Fiji Islands Marine Ecoregion. WWF-Fiji, Suva, Fiji. Http://assets. panda.org/downloads/fime_rpt.pdf [accessed 1 September 2009]. 
Yanega, D., Olson, D., Shute, S. \& Komiye, Z. (2004) The Xixuthrus species of Fiji (Coleoptera: Cerambycidae: Prioninae). Zootaxa, 777, 1-10.

Zona, S. \& Fuller, D. (1999) A revision of Veitchia (ArecaceaeArecoideae). Harvard Papers in Botany, 4, 543-560.

Zug, G.R. (1991) Lizards of Fiji: Natural History and Systematics. Bishop Museum Press, Honolulu, Hawaii.

Zug, G.R., Springer, V.G., Williams, J.T. \& Johnson, G.D. (1988) The vertebrates of Rotuma and surrounding waters. Atoll Research Bulletin, 316, 1-25.

\section{Appendices 1-2}

The appendices for this article are available online at http:// journals.cambridge.org

\section{Biographical sketches}

The authors are naturalists, scientists, conservationists, natural resource managers, foresters, field researchers and conservation geographical information system specialists who share an interest in, and concern for, the future of Fiji's forests. They share a belief that a functional balance between conservation and sustainable development, livelihoods and quality of life for Fijians is attainable through science-based analyses, participatory planning and decision-making, respect for tradition, and partnerships and collaboration among all stakeholders. The decisions Fijians make today about preserving their natural wealth and heritage are critical because opportunities are likely to diminish in the coming decades if trajectories of forest loss continue. This analysis is a contribution from the authors' collective efforts to find the balance. 